\title{
Analiza wpływu lokalizacji stacji metra warszawskiego na ceny mieszkań na przykładzie dzielnicy Ursynów w Warszawie
}

\author{
Marcin Torzewski
}

\begin{abstract}
Metro warszawskie petni kluczowa funkcje w uktadzie komunikacji zbiorowej stolicy: z jednej strony znacząco skraca czas podróży z dzielnic peryferyjnych Warszawy do Centrum, z drugiej zaś - utatwia przemieszczanie w samym sercu miasta. Należy zatem oczekiwać, że pozytywny aspekt bliskości metra powinien zostać skapitalizowany przez wartość okolicznych nieruchomości. Celem artykutu jest przedstawienie wyników badania empirycznego, polegającego na analizie wplywu lokalizacji stacji metra warszawskiego (I linia) na ceny nieruchomości mieszkalnych, na przyktadzie rynku pierwotnego dzielnicy Ursynów (Warszawa). Hipoteza główna pracy zakłada, że wzrost odlegtości lokalu mieszkalnego od stacji metra negatywnie wptywa na cene nieruchomości. Do zbadania tej zależności wykorzystano hedonistyczny model cen. Ponadto, do pomiaru odlegtości stacji metra od nieruchomości-zamiast tradycyjnie wykorzystywanej odlegtości euklidesowej - postużono się modutem GPS. Wyniki potwierdzaja hipoteze badania, wykazujac, że wzrost odlegtości lokalizacji mieszkania od stacji metra o $1 \mathrm{~km}$ powoduje na badanym obszarze spadek ceny nieruchomości o ok. 172 zt/m² lub 2,35\%.
\end{abstract}

Słowa kluczowe: hedonistyczny model cen, ceny mieszkań, wpływ metra, odległość od stacji metra.

Nadesłany: 09.02.2016 | Zaakceptowany do druku: 07.05.2016

\section{The analysis of the impact of the Warsaw metro stations location on residential property prices in Ursynow district in Warsaw}

The Warsaw metro plays a key role in the public transport system of the capital: on the one hand, it significantly reduces travel time from peripheries of city to the centre, and on the other hand it makes it easier to commute inside the city. Therefore one could expect that the positive aspects of metro existence should be capitalized by the nearby property values. The purpose of this article is to present the results of an empirical analysis on the impact of the Warsaw metro stations (I line) location on property prices, based on the primary residential market of Ursynow district (Warsaw). The main hypothesis assumes that the distance of a property from the subway station negatively affects a property price. To examine this relationship a hedonic pricing model is applied. Moreover, instead of the traditional approach to measure the distance with the Euclidean metric, the distance between the metro station and the property is measured with the use of GPS module. The results confirm the research hypothesis, showing that an increase of $1 \mathrm{~km}$ in the distance between the metro station and the real estate leads to the decline in the property price by approximately $172 \mathrm{PLN} / \mathrm{m}^{2}$ or $2.35 \%$.

\footnotetext{
* Marcin Torzewski - doktorant Wydziału Zarządzania Uniwersytetu Warszawskiego, Katedra Finansów i Rachunkowości

Adres do korespondencji: Wydział Zarządzania Uniwersytetu Warszawskiego, Katedry Finansów i Rachunkowości, ul. Szturmowa 1/3, 02-678 Warszawa; e-mail: m.torzewski@hotmail.com.
} 
Keywords: hedonic pricing model, residential property prices, metro causal effect, metro station proximity.

Submitted: 09.02.2016 | Accepted: 07.05.2016

JEL: C10, O18, R3

\section{Wprowadzenie}

W świadomości społecznej rozwój infrastruktury transportowej pozytywnie wpływa na urbanizację otoczenia. W układzie transportowym wysoce rozwiniętych miast metro pełni kluczową funkcję, przyczyniając się do ograniczenia liczby samochodów w obszarze śródmiejskim, tworzenia węzłów przesiadkowych oraz skrócenia czasu podróży. Ma ono również niebagatelne znaczenie dla terenów znajdujacych się wzdłuż korytarza, którym biegnie linia metra. Bliskość metra jest więc magnesem, który przyciąga biznes oraz usługi. Pozytywne aspekty bliskości lokalizacji metra powinny zatem zostać skapitalizowane przez wartość okolicznych nieruchomości.

$\mathrm{Na}$ przestrzeni lat, wraz $\mathrm{z}$ rozbudową sieci transportowej metra, obserwowano rosnące zainteresowanie analizą wpływu tego rodzaju transportu na otoczenie. Większość badań dotyczy jednak miast o wysoce rozwiniętej infrastrukturze sieci kolejowej (zob. Damm, Lerman, LernerLam i Young, 1980; Gatzlaff i Smith, 1993; Bae, Jun i Park, 2003; Lin i Hwang, 2004; Zhang i Jing, 2014). Analizowane miasta różnią się przy tym znacząco w zakresie samej sieci transportowej i komunikacyjnej, a także pod względem uwarunkowań socjoekonomicznych. Oznacza to, że wyników tych badań nie można i nie należy transponować na inne miasta, przez które przebiega linia metra, a dla których wciąż brak jest podobnych analiz.

Analiza i ocena wpływu, jaki ma I linia metra warszawskiego w kształtowaniu się cen nieruchomości wydaje się więc ważnym problemem badawczym, zwłaszcza że w krajowej literaturze naukowej brakuje badań empirycznych, dotyczących wskazanej problematyki ${ }^{1}$. Taki stan rzeczy może być wynikiem m.in. znacznie ograniczonej dostępności rzetelnych źródeł danych, niezbędnych do analizy problemu. W istniejących bazach cen nieruchomości dane zbierane są bowiem na podstawie aktów notarialnych transakcji kupna-sprzedaży.
W związku z brakiem jednolitego standardu uzupełniania aktów notarialnych tak zgromadzone dane często nie dostarczają ważnych - dla analizy empirycznej - informacji, w szczególności o charakterze jakościowym, takich jak ocena stanu technicznego i standardu nieruchomości.

Niniejszy artykuł ma na celu uzupełnienie wiedzy dotyczącej skutków lokalizacji metra na cenę pobliskich nieruchomości poprzez analizę tego zagadnienia dla warszawskiej linii metra. Głównym celem tego artykułu jest przede wszystkim przedstawienie wyników badania empirycznego, polegającego na analizie wpływu lokalizacji stacji I linii metra warszawskiego na ceny nieruchomości mieszkalnych. Hipoteza główna pracy zakłada, że odległość lokalu mieszkalnego od stacji metra negatywnie wpływa na cenę nieruchomości.

Do zbadania zależności pomiędzy lokalizacją stacji metra a ceną nieruchomości wykorzystano hedonistyczny model cen (ang. hedonic pricing model), oparty na regresji wielorakiej. Badanie zostało przeprowadzone dla lokali mieszkalnych usytuowanych $\mathrm{w}$ budynkach wielorodzinnych. W odróżnieniu od dotychczasowych badań przeprowadzonych dla Polski (Bazyl, 2009), opierających się na cenach ofertowych, niniejsza analiza wykorzystuje ceny transakcyjne. Do weryfikacji hipotezy posłużono się danymi dotyczącymi cen transakcyjnych zarejestrowanych w latach 2013-2014 oraz cech nieruchomości pobranych z bazy danych Katastru Nieruchomości m.st. Warszawy. Ponadto do pomiaru odległości w niniejszej pracy posłużono się modułem GPS dla trybu pieszego ${ }^{2}$, który pozwala uzyskać dokładniejsze oszacowania dystansu niż przy założeniu pomiaru odległości w linii prostej (miara euklidesowa). Analiza uwzględnia również wpływ innych środków transportu komunikacji zbiorowej (dostępność komunikacji autobusowej). Mając na uwadze specyfikę poszczególnych rynków lokalnych w Warszawie, badanie ograniczono do analizy rynku pierwotnego w dzielnicy Ursynów. 
Wyniki oszacowanego modelu potwierdzają hipotezę główną badania o statystycznie istotnym wpływie lokalizacji stacji metra na cenę nieruchomości. Należy oczekiwać, że wzrost odległości lokalizacji mieszkania od stacji metra o $1 \mathrm{~km}$ spowoduje na badanym obszarze liniowy spadek ceny nieruchomości o ok. 2,35\% lub alternatywnie $172 \mathrm{zl} / \mathrm{m}^{2}$. Pozostałe wyniki badania sa zgodne $\mathrm{z}$ oczekiwaniami: prawo własności gruntu wpływa pozytywnie na cenę nieruchomości; wraz ze wzrostem powierzchni użytkowej jednostkowa cena nieruchomości spada; im bliżej zlokalizowany jest przystanek autobusowy od mieszkania, tym cena jest wyższa.

Niniejszy artykuł składa się z części: w części 2 przedstawiono przegląd literatury; w części 3 zaprezentowano źródła danych; w części 4 zdefiniowano specyfikację modelu, określając metodę badawczą, cel i zakres analizy oraz wybór postaci analitycznej modelu. W części 5 przedstawiono wyniki estymacji i weryfikacji modelu ekonometrycznego oraz ich interpretację; w części 6 zaprezentowano podsumowanie i wnioski z analizy.

\section{Przegląd literatury}

Wpływ lokalizacji systemu kolejowego w tym metra - na ceny nieruchomości jest stosunkowo szeroko analizowany w literaturze zagranicznej. Większość dotychczasowych badań skupia sie na analizie systemów konwencjonalnych kolei sieci krajowej lub regionalnej. $\mathrm{W}$ ostatnim czasie, wraz ze wzrostem znaczenia metra jako rodzaju szybkiej kolei miejskiej o dużej zdolności przewozowej, uwagę poświęca się również analizie wpływu lokalizacji metra na ceny nieruchomości miejskich (zob. Bae i in., 2003; Lin i Hwang 2004; Martínez i Viegas, 2009; Efthymiou i Antoniou, 2013; Zhang i Jing, 2014).

Od strony metodologicznej do badania zależności pomiędzy lokalizacją stacji metra a ceną pobliskich nieruchomości najczęściej wykorzystuje się tzw. hedonistyczny model cen, oparty na regresji wielorakiej. W celu wyeliminowania problemów metodologicznych, takich jak heteroskedastyczność składnika losowego i autokorelacja przestrzenna, badacze wykorzystuja również inne podejścia i metody badawcze, w tym m.in. modele powtórnej sprzedaży/ wynajmu (np. Gatzlaff i Smith, 1993; Sun $\mathrm{i}$ in., 2015), modele difference-in-difference (np. Agostini, i Palmucci, 2008).

Większość badań dotyczących wpływu dostępności metra na cenę nieruchomości za punkt odniesienia przyjmuje układ przestrzenny. Dostępność danego obiektu (stacji metra) jest mierzona za pomoca odległości euklidesowej (np. Agostini, i Palmucci, 2008; Bazyl, 2009; Sun, Zheng i Wang, 2015). Pomiar odbywa się z wykorzystaniem oprogramowania GIS. Takie uproszczenie pozwala na przeprowadzenie analizy dla dużej próby, jednakże otrzymane wyniki mogą być obciążone, ponieważ $w$ analizie nie są uwzględnione inne obiekty leżące na odcinku łączącym oba punkty. Rozwiązaniem tego problemu wydaje się zastosowanie odległości rzeczywistej, uwzględniającej obiekty spotykane na drodze, lub pomiaru czasowego.

Wyniki badań zagranicznych wykazują w większości pozytywny wpływ dostepności metra na cenę nieruchomości, choć różnia się one pod względem interpretacji i poziomu istotności wyników. Przykładowo, Bae i in. (2002) zbadali wpływ lokalizacji stacji jednej z linii metra na ceny mieszkań w Seulu (Korea Płd.). Autorzy dowiedli, że metro w największym stopniu wpływa na ceny nieruchomości przed faktycznym otwarciem linii metra (zgodne z tzw. efektem antycypacyjnym). Ponadto, wpływ metra jest niższy niż innych ważnych czynników określających cenę nieruchomości (np. powierzchnia mieszkania, dostępność terenów rekreacyjnych czy szkół). Zauważyli również, że dostepność stacji metra ma większy wpływ w okolicach, w których inne linie metra nie sa dostepne. W odróżnieniu od analizy Bae i in. (2002) Lin i Hwang (2004) - na przykładzie linii metra w Tajpej (Tajwan) - wykazały pozytywny wpływ lokalizacji metra na ceny nieruchomości w okresie po uruchomieniu stacji metra. Zauważyły ponadto, że wpływ ten jest zmienny w zależności m.in. od lokalizacji nieruchomości (centrum czy peryferia), przeznaczenia nieruchomości (mieszkalne czy komercyjne).

Analogicznie do efektów odziaływania innych rodzajów transportu szynowego (kolejowego, tramwajowego) dostrzegalny jest również negatywny aspekt bliskości stacji metra. $Z$ reguły jest on jednak kompensowany przez korzyści związane z lokalizacją metra. Bowes (2001) zidentyfikował cztery rodzaje czynników związanych 
z obecnością stacji kolejowych, które moga mieć wpływ na cenę nieruchomości. Wśród pozytywnych stron bliskości stacji wyróżnia: (1) korzyści związane $z$ dostępnością komunikacyjną oraz (2) czynnik zachęcający biznes do relokowania swoich usług w pobliżu stacji. Natomiast negatywne strony bliskości stacji to w szczególności: (3) czynniki środowiskowe, takie jak: hałas, drgania, zanieczyszczenia oraz (4) wzrost drobnej przestępczości.

W przypadku Polski i metra warszawskiego Bazyl (2009) przeprowadziła badanie empiryczne dla warszawskich lokali mieszkalnych, analizując wpływ cech fizycznych nieruchomości i atrybutów otoczenia (m.in. odległość od stacji I linii metra warszawskiego, lotniska, terenów zielonych) na ceny ofertowe nieruchomości w $2006 \mathrm{r}$. na próbie ponad 2 tys. obserwacji. Badanie wykazało, że nieruchomości zlokalizowane w odległości do $1 \mathrm{~km}$ od stacji metra są droższe o $15 \%$ w stosunku do nieruchomości znajdujących się poza ta strefą Interpretacja otrzymanych wyników jest jednak stosunkowo ograniczona, głównie z powodu zastosowanych miar odległości oraz zakresu terytorialnego. Analiza była bowiem przeprowadzona $\mathrm{z}$ wykorzystaniem odległości euklidesowej, tj. łączącej linią prostą dwa punkty (obserwację i obiekt referencyjny) o określonych współrzędnych geograficznych. Ponadto, z powodu braku dokładnych współrzędnych geograficznych dla lokalizacji obserwacji, zrezygnowano $\mathrm{z}$ uwzględnienia $\mathrm{w}$ analizie lokali położonych przy ulicach o długości powyżej $0,5 \mathrm{~km}$. W analizowanej próbie znalazły się również mieszkania zlokalizowane w dzielnicach, przez które nie przebiegała linia metra.

\section{3. Źródła danych}

W badaniu posłużono się danymi przekrojowymi, dotyczącymi cen transakcyjnych oraz cech nieruchomości. Dane te pochodzą z Rejestru Cen i Wartości Nieruchomości, prowadzonego przez Urząd m.st. Warszawy.

Obszar, dla którego dokonano analizy wpływu dostępności metra na ceny okolicznych nieruchomości, został zawężony do transakcji z rynku pierwotnego (deweloperskiego) z dzielnicy Ursynów w Warszawie w okresie 2013-2014, przez która przebiega I linia metra (M1) warszawskiego na odcinku Ursynów-Kabaty. Linia metra na analizowanym odcinku Ursynów-Kabaty ma długość ok. 4,25 km i składa się z 5 stacji metra: Ursynów, Stokłosy, Imielin, Natolin i Kabaty. Odcinek metra Ursynów-Kabaty został oddany do użytku w 1995 r. w ramach uruchomionej pierwszej czéści linii M1, łączącej Kabaty ze Śródmieściem (stacja Politechnika).

Założono, że wszystkie lokale oraz budynki, w których usytuowane są lokale, mają podobny stan techniczny i standard wykończenia. Jest to podyktowane uwzględnieniem $\mathrm{w}$ analizie jedynie transakcji z rynku pierwotnego, a więc wyłącznie nowych lokali w stanie tzw. deweloperskim.

W tabeli 1 przedstawiono podstawowe statystyki opisowe wybranych zmiennych.

Tabela 1. Statystyki opisowe wybranych zmiennych

\begin{tabular}{|l|r|c|c|c|}
\hline \multicolumn{1}{|c|}{ Zmienn-a(e) } & Średnia & $\begin{array}{c}\text { Odchylenie } \\
\text { standardowe }\end{array}$ & Minimum & Maksimum \\
\hline Cena transakcyjna (zt/m²) & 7622,80 & 730,39 & 6306,00 & 9840,00 \\
\hline Położenie lokalu na piętrze (nr kondygnacji) & 4,54 & 2,63 & 1 & 11 \\
\hline Odległość od stacji metra (m) & 1328,57 & 855,46 & 400 & 3800 \\
\hline Odległość od przystanku autobusowego (m) & 226,35 & 115,08 & 20 & 600 \\
\hline Odległość od Centrum (km) & 11,11 & 0,90 & 10 & 14 \\
\hline Liczba obserwacji & \multicolumn{5}{|c|}{126} \\
\hline Okres badania & \multicolumn{5}{|c|}{$07.2013-11.2014$} \\
\hline
\end{tabular}

Źródło: opracowanie własne na podstawie danych Rejestru Cen i Wartości Nieruchomości. 


\section{Specyfikacja modelu}

\subsection{Metoda badawcza}

Do zbadania wpływu lokalizacji stacji metra na cenę nieruchomości wykorzystano hedonistyczny model cen (HMC). Za prekursora teoretycznych rozważań dotyczących aplikacji HMC powszechnie uważa się amerykańskiego ekonomistę Sherwina Rosena (1974). Przyjął on tzw. hedonistyczną hipotezę, że dobra zróżnicowane są agregatami charakterystyk, które stanowią podstawe wyborów ekonomicznych przez konsumentów. Model ten został inkorporowany na potrzeby badań empirycznych dotyczących kształtowania się cen nieruchomości. Przyjmuje się, że zmienna objaśniana w HMC, czyli cena nieruchomości, determinowana jest zarówno przez charakterystyki wewnętrzne (fizyczne cechy), jak i czynniki zewnętrzne (otoczenie) w stosunku do nieruchomości (Sirmans, Macpherson i Zietz, 2005). Uproszczona postać funkcyjna HMC wygląda następująco:

\section{Cena $=f($ fizyczne cechy nieruchomości, atrybuty otoczenia)}

W HMC cena nieruchomości opisana jest więc jako funkcja określonych cech nieruchomości i otoczenia. Fizyczne atrybuty nieruchomości odnoszą się np. do parametrów powierzchniowych, wieku budynku, położenia na piętrze; natomiast cechy otoczenia dotyczą przede wszystkim lokalizacji i innych czynników zewnętrznych (np. odległość od stacji metra), wpływających na cenę. Do budowy HMC powszechnie wykorzystywana jest regresja liniowa, która umożliwia analizę wpływu zmiennych objaśniających (przy założeniu ceteris paribus) na zmienną objaśniana cenę nieruchomości. W celu uproszczenia interpretacji współczynników regresji często stosowanym rozwiązaniem jest transformacja postaci funkcyjnej zmiennej objaśnianej do logarytmu naturalnego ceny (model log-liniowy). Wówczas oszacowane parametry równania mogą być interpretowane jako procentowa zmiana zmiennej objaśnianej (ceny), spowodowana jednostkową zmianą zmiennej objaśniającej (Wooldridge, 2003) ${ }^{3}$. Zastosowanie logarytmicznej postaci funkcyjnej zmiennej objaśnianej pozwala również w pewnym stopniu zniwelować problem heteroskedastyczno- ści wariancji reszt składnika losowego (Lin i Hwang, 2004).

\subsection{Cel badania i hipotezy badawcze}

Celem głównym badania empirycznego jest analiza wpływu dostępności stacji metra w układzie przestrzennym na cenę nieruchomości.

W ramach badania sformułowano następującą hipoteze główną: wzrost odległości lokalu mieszkalnego od stacji metra wpływa negatywnie na cenę nieruchomości. Weryfikacja hipotezy odbywa się za pomocą oceny istotności statystycznej współczynnika regresji, stojącego przy zmiennej objaśniającej, określającej odległość od metra. Do weryfikacji hipotezy posłużono się dwustronnym testem t-Studenta. W badaniu przejęto poziom istotności $\alpha=0,05$.

Poboczne cele badania stanowi analiza wpływu pozostałych czynników (cechy fizyczne nieruchomości oraz atrybuty otoczenia) na cenę nieruchomości. W szczególności oczekuje się, że:

- wraz ze spadkiem powierzchni użytkowej lokalu rośnie cena jednostkowa mieszkania;

- prawo własności do gruntu wpływa pozytywnie na cenę nieruchomości;

- mieszkania na parterze są tańsze niż na pozostałych piętrach;

- mieszkania zlokalizowane bliżej Centrum Warszawy sa droższe;

- mieszkania zlokalizowane bliżej przystanków autobusowych są droższe.

\subsection{Określenie potencjalnych zmiennych objaśniających Xj}

Lista zmiennych objaśniajacych, które zgodnie $\mathrm{z}$ przesłankami teoretycznymi moga mieć istotny wpływ na kształtowanie się cen nieruchomości, została przedstawiona w tabeli 2 .

\subsection{Wybór postaci analitycznej modelu}

Doboru postaci analitycznej modelu dokonano na podstawie istniejących badań dotyczących związku lączącego zmienne objaśniające (cechy nieruchomości i atrybuty otoczenia) ze zmienna objaśniana (ceną nieruchomości). W analizie posłużono się HMC, wykorzystującym równanie regresji liniowej. W przypadku większości badań empirycznych bazujących na HMC zmienna objaśniana określająca cenę nieruchomości, przedstawiana jest albo jako zmienna ciągła, albo jako zmienna zloga- 
Tabela 2. Charakterystyka zmiennych objaśniających

\begin{tabular}{|c|c|c|c|}
\hline & Zmienna Xj & Definicja & Charakterystyka \\
\hline \multirow{8}{*}{ 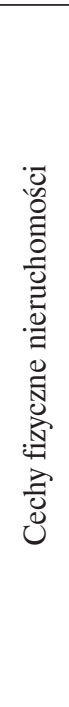 } & PU_do45 & $\begin{array}{l}1-\text { dla PU } \leq 45 \mathrm{~m}^{2} \\
0-\text { inna PU }\end{array}$ & \multirow{4}{*}{$\begin{array}{l}\text { Powierzchnia użytkowa } \\
\text { mieszkania }\left(\mathrm{m}^{2}\right)\end{array}$} \\
\hline & PU_45do60 & $\begin{array}{l}1-\text { dla } P U \in\left(45 ; 60>\mathrm{m}^{2}\right. \\
0-\text { inna PU }\end{array}$ & \\
\hline & PU_60do90 & $\begin{array}{l}1-\text { dla } P U \in\left(60 ; 90>\mathrm{m}^{2}\right. \\
0-\text { inna PU }\end{array}$ & \\
\hline & PU_od90 & $\begin{array}{l}1-\text { dla } \mathrm{PU} \geq 90 \mathrm{~m}^{2} \\
0-\text { inna PU }\end{array}$ & \\
\hline & WLASN & $\begin{array}{l}1 \text { - własność gruntu } \\
0 \text { - użytkowanie wieczyste gruntu }\end{array}$ & Rodzaj prawa do gruntu \\
\hline & PARTER & $\begin{array}{l}1 \text { - dla kondygnacji } 1 \text { lokalu } \\
0 \text { - inna kondygnacja lokalu }\end{array}$ & \multirow{3}{*}{$\begin{array}{l}\text { Położenie lokalu na piętrze } \\
\text { (kondygnacja) }\end{array}$} \\
\hline & PIETRO_1lub2 & $\begin{array}{l}1 \text { - dla kondygnacji } 2 \text { lub } 3 \text { lokalu } \\
0 \text { - inna kondygnacja lokalu }\end{array}$ & \\
\hline & PIETRO_od3 & $\begin{array}{l}1 \text { - dla kondygnacji } \geq 4 \\
0 \text { - inna kondygnacja lokalu }\end{array}$ & \\
\hline \multirow{3}{*}{ 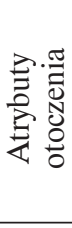 } & METRO & Zmienna ciągła (w metrach) & Odległość od stacji metra (m) \\
\hline & BUS_do200 & $\begin{array}{l}1 \text { - przystanek autobusowy do } 200 \mathrm{~m} \\
0 \text { - przystanek autobusowy powyżej } 200 \mathrm{~m}\end{array}$ & $\begin{array}{l}\text { Odległość od przystanku } \\
\text { autobusowego }\end{array}$ \\
\hline & CENTR_do10 & $\begin{array}{l}1 \text { - Centrum do } 10 \mathrm{~km} \\
0 \text { - Centrum powyżej } 10 \mathrm{~km}\end{array}$ & $\begin{array}{l}\text { Odległość od Centrum } \\
\text { Warszawy }\end{array}$ \\
\hline & Y2014 & Y2014 - 1 dla 2014 r.; 0 - dla 2013 r. & Rok zawarcia transakcji \\
\hline
\end{tabular}

Źródło: opracowanie własne.

rytmowana (por. Damm i in., 1980, Bae, 2003; Lin i Hwang, 2004; Bazyl, 2009; Zhang i Jiang, 2014). Na potrzeby niniejszego badania wyjściową postać analityczną modelu zdefiniowano przy założeniu, że cena nieruchomości jest zmienną ciągłą:

$$
\text { CENA_TRANS }=\boldsymbol{\beta}_{0}+\sum_{k=1}^{K} \beta_{k i} X_{k i}+\boldsymbol{\varepsilon}_{i}
$$

gdzie:

CENA TRANS - zmienna objaśniana cena transakcyjna wyrażona w zł na $1 \mathrm{~m}^{2}$;

$\beta_{0}-$ parametr strukturalny wyrazu wolnego,

$X_{k i}$ - zmienne objaśniające,

$\beta_{k i}$ - parametr pokazujący zmianę jednostkowa zmiennej objaśnianej na skutek zmiany o jednostkę zmiennej $X_{k i}$,

$\varepsilon_{i}-$ składnik losowy.

Do estymacji nieznanych parametrów $\beta_{k}$ modelu zastosowano klasyczną metodę naj- mniejszych kwadratow (KMNK), z wykorzystaniem programu komputerowego Gretl.

\section{Estymacja i weryfikacja modelu ekonometrycznego}

\subsection{Testowanie modelu}

W tabeli 3 przedstawiono wyniki oszacowania modelu liniowego (model nr 1) z wykorzystaniem KMNK.

Przed weryfikacja istotności wpływu poszczególnych zmiennych objaśniających $X_{j}$ na zmienna objaśniana przystapiono do zbadania założeń KMNK. W szczególności zbadano założenie normalności rozkładu oraz homoskedastyczności składnika losowego. W przypadku niespełnienia założeń stochastycznych otrzymane oszacowania parametrów strukturalnych modelu są niezgodne, obciążone i/lub nieefektywne.

W celu oceny normalności rozkładu resztkowego przeprowadzono test Jarque'a- 
Tabela 3. Wyniki estymacji KMNK dla modelu 1

\begin{tabular}{|c|c|c|c|c|c|}
\hline Zmienna & Współczynnik & Błąd stand. & t-Studenta & wartość $p$ & \\
\hline METRO & $-0,2511$ & 0,1135 & $-2,2133$ & 0,0288 & $* *$ \\
\hline WLASN & 957,0650 & 167,8950 & 5,7004 & $<0,0001$ & $* * *$ \\
\hline BUS_do200 & 402,8900 & 172,4580 & 2,3362 & 0,0212 & $* *$ \\
\hline PU_do45 & 974,0740 & 236,5670 & 4,1175 & $<0,0001$ & $* * *$ \\
\hline PU_od45do60 & 169,9720 & 153,3530 & 1,1084 & 0,2700 & \\
\hline PU_60do90 & $-87,0367$ & 144,5580 & $-0,6021$ & 0,5483 & \\
\hline PARTER & $-103,2020$ & 234,3260 & $-0,4404$ & 0,6605 & \\
\hline PIETRO_1lub2 & $-80,0696$ & 113,6270 & $-0,7047$ & 0,4824 & \\
\hline CENTR_do10 & 195,7630 & 232,5330 & 0,8419 & 0,4016 & \\
\hline Y2014 & $-101,9470$ & 119,0190 & $-0,8566$ & 0,3935 & \\
\hline Const & 7143,7400 & 209,9570 & 34,0248 & $<0,0001$ & $* * *$ \\
\hline $\mathrm{N}$ & \multicolumn{5}{|c|}{126} \\
\hline $\mathrm{R}^{2}$ & \multicolumn{5}{|c|}{0,4428} \\
\hline Skoryg. R2 & \multicolumn{5}{|c|}{0,3944} \\
\hline
\end{tabular}

Uwagi: zmienna zależna (Y): CENA_TRANS; $\quad{ }^{*},{ }^{* *},{ }^{* * *}$ oznaczają poziom istotności odpowiednio: 0,1; 0,05 i 0,01 .

-Bery na normalność reszt, którego hipoteza zerowa zakłada, że składnik losowy ma rozkład normalny. Otrzymany empiryczny poziom istotności dla tego testu wyniósł $\mathrm{p}=0,82$, wobec czego nie ma podstaw do odrzucenia hipotezy zerowej ( $\operatorname{przy} \alpha=0,05)$ o normalnym rozkładzie reszt.

W celu weryfikacji założenia homoskedastyczności składnika losowego wykonano test White'a na ocenę jednorodności wariancji składnika losowego, którego hipoteza zerowa zakłada, że składnik losowy modelu jest homoskedastyczny. Otrzymany empiryczny poziom istotności dla tego testu wyniósł $\mathrm{p}=0,15$, wobec czego nie ma podstaw do odrzucenia hipotezy zerowej (dla $\alpha=0,05)$ o homoskedastyczności składnika losowego.

Następnym ważnym problemem mogącym prowadzić do nieprawidłowych wniosków dotyczących szacowanego wpływu jest problem współliniowości zmiennych objaśniających. W celu zweryfikowania, czy problem ten występuje, dokonano oceny stopnia współliniowości zmiennych za pomocą miary VIF (ang. variance inflation factors). W przypadku VIF $>10$, występuje współliniowość między zmiennymi. Test na współliniowość zmiennych VIF wykazał, że w oszacowanym modelu stopień skorelowania poszczególnych zmiennych objaśniających zawierał się w przedziale od 1,39 do 3,83, a więc należy oczekiwać, że w modelu nie występuje problem współliniowości zmiennych.

Ponadto, dokonano oceny poprawności formy funkcyjnej modelu. Postać funkcyjna modelu powinna być podyktowana merytorycznymi przesłankami, a dobór niewłaściwej postaci funkcyjnej modelu może być przyczyną jego słabości. W celu sprawdzenia, czy zaproponowany model liniowy jest właściwy, dokonano oceny liniowości modelu. W tym celu weryfikacji poddano model w postaci liniowej (model nr 1) względem:

- modelu potęgowego, wykonując test nieliniowości dla postaci logarytmicznej;

- modelu kwadratowego, wykonując test nieliniowości dla postaci kwadratowej. Testy nieliniowości dla logarytmów i kwadratów wykazały, że nie ma podstaw do odrzucenia $\mathrm{H}_{0}$, mówiącej o liniowej zależności, ponieważ wartość empiryczna w obu przypadkach (odpowiednio $\mathrm{p}=0,18$ i $p=0,18)$ jest większa od przyjętego poziomu istotności $\alpha=0,05$. Do dalszej analizy przyjęto zatem liniową postać funkcyjną modelu. 


\subsection{Ocena stopnia precyzji modelu}

Ocena stopnia wyjaśnienia zmienności zmiennej objaśnianej dokonywana jest za pomoca współczynnika determinacji $\mathrm{R}^{2}$ W rozważanym modelu wartość $\mathrm{R}^{2}$ wynosi 0,44 - co oznacza, że zmienność zmiennych objaśniających w 44\% wyjaśnia kształtowanie się zmienności zmiennej objaśnianej (ceny transakcyjnej).

\subsection{Ocena istotności oraz interpretacja otrzymanych parametrów strukturalnych modelu}

Analizując otrzymane wyniki przedstawione w tabeli 3, należy stwierdzić, że znaki przy oszacowaniach parametrów zmiennych objaśniających są zgodne z oczekiwaniami sformułowanymi na bazie teorii ekonomii i istniejących badań empirycznych. Nie wszystkie oszacowane parametry modelu sa jednak istotnie statystycznie różne od zera. Wyniki oszacowania modelu nr 1 wskazują, że przy założonym poziomie istotności $\alpha=0,05$ parametry istotnie różniące się od zera to współczynniki określajace wpływ nastepujacych zmiennych: WLASN, METRO, PU do45, BUS do200. W przypadku pozostałych zmiennych poziomy istotności oszacowanych parametrów (w tym m.in.: Y2014, PARTER, PIETRO_1lub2, CENTR_do10) są powyżej ustalonego poziomu istotności $\alpha=0,05$.

Zgodnie z główną hipotezą mówiącą o negatywnym wpływie lokalizacji stacji metra na cene nieruchomości, znak przy zmiennej METRO jest ujemny. Interpretacja oszacowanego parametru jest nastę- pująca: wraz ze wzrostem dystansu nieruchomości od stacji metra o $1 \mathrm{~km}$, cena mieszkania (ceteris paribus) spada o ok. 251 $\mathrm{z} 1 / \mathrm{m}^{2}$. W przypadku parametrów oszacowanych dla pozostałych zmiennych ich znaki są zgodne $\mathrm{z}$ hipotezami pobocznymi:

- prawo do gruntu w postaci własności w stosunku do użytkowania wieczystego - ma pozytywny wpływ na cene, powodując jej wzrost (ceteris paribus) o ok. $957 \mathrm{zl} / \mathrm{m}^{2}$.

- mieszkania o najmniejszej powierzchni użytkowej (do $45 \mathrm{~m}^{2}$ ) są droższe (ceteris paribus) niż mieszkania o większej powierzchni (powyżej $90 \mathrm{~m}^{2}$ ) o ok $974 \mathrm{zt} / \mathrm{m}^{2}$;

- lokalizacja mieszkania w pobliżu przystanku autobusowego (w odległości do $200 \mathrm{~m}$ ) wpływa pozytywnie (ceteris paribus) na cene nieruchomości o ok. $403 \mathrm{zl} / \mathrm{m}^{2}$.

Korzystajac z metody selekcji zmiennych objaśniających a posteriori, z modelu nr 1 wyeliminowane zostały kolejno zmienne o najwyższym poziomie prawdopodobień stwa popełnienia błędu, przy odrzuceniu hipotezy o braku wpływu zmiennej objaśniającej na cenę. W konsekwencji oszacowany model nr 2, zawierający zmienne istotne statystycznie, przedstawia się tak, jak zaprezentowano w tabeli 4.

W przypadku modelu nr 2 oszacowania wskazują na statystycznie istotny wpływ lokalizacji stacji metra na cenę nieruchomości. Wyniki estymacji różnią się nieznacznie od modelu nr 1 , z tym że poza zmienną BUS do200 wzrósł poziom istotności para-

Tabela 4. Wyniki estymacji KMNK dla modelu 2

\begin{tabular}{|c|c|c|c|c|c|}
\hline Zmienna & Współczynnik & Błąd stand. & t-Studenta & wartość p & \\
\hline METRO & $-0,171913$ & 0,0686 & $-2,5075$ & 0,0135 & $* *$ \\
\hline WLASN & 865,4740 & 143,5910 & 6,0273 & $<0,0001$ & **** \\
\hline BUS_do200 & 308,5320 & 157,7730 & 1,9555 & 0,0528 & $*$ \\
\hline PU_do45 & 996,9520 & 211,9140 & 4,7045 & $<0,0001$ & $* * *$ \\
\hline PU_od45do60 & 255,2290 & 112,1790 & 2,2752 & 0,0247 & $* *$ \\
\hline Const & 7059,2400 & 184,4460 & 38,2727 & $<0,0001$ & $* * *$ \\
\hline $\mathrm{N}$ & \multicolumn{5}{|c|}{126} \\
\hline $\mathrm{R}^{2}$ & \multicolumn{5}{|c|}{0,4292} \\
\hline Skoryg. R ${ }^{2}$ & \multicolumn{5}{|c|}{0,4054} \\
\hline
\end{tabular}

Uwagi: zmienna zależna (Y): CENA_TRANS; $\quad *, * *, * * *$ oznaczają poziom istotności odpowiednio: 0,1; 0,05 i 0,01 . 
metrów zmiennej METRO, a ponadto parametr przy zmiennej PU_od45do60 okazał się istotnie różny od zera. Natomiast porównanie precyzji modelu $\mathrm{nr} 1$ i nr 2 poprzez zestawienie ze sobą wysokości skorygowanych $\mathrm{R}^{2}$ również wypada nieznacznie na korzyść modelu nr 2.

Przy założonym poziomie istotności $\alpha=0,05$ otrzymany empiryczny poziom istotności dla oszacowania parametru stojącego przy zmiennej METRO wyniósł $\mathrm{p}=0,0135$, co oznacza, że oszacowanie parametru przy zmiennej METRO jest statystycznie istotnie różne od zera. Wartość oszacowanego parametru wyniosła przy tym $-0,172$, co oznacza, że wzrost odległości od nieruchomości do stacji metra o $1 \mathrm{~km}$ prowadzi do spadku (ceteris paribus) ceny nieruchomości o ok. $172 \mathrm{zł} / \mathrm{m}^{2}$.

W przypadku pozostałych zmiennych modelu nr 2 oszacowania parametrów również są statystycznie istotnie różne od zera. Interpretacje wyników są następujące:

- prawo własności (WLASN) do gruntu i części wspólnych budynku wpływa pozytywnie (ceteris paribus) na cenę nieruchomości w stosunku do prawa użytkowania wieczystego o ok. $865 \mathrm{zl} / \mathrm{m}^{2}$; - powierzchnie użytkowe mieszkania poniżej $45 \mathrm{~m}^{2}$ (PU_do45) i między 45-60 m² (PU_od45do60) wpływają pozytywnie (ceteris paribus) na cenę nieruchomości względem mieszkań powyżej $60 \mathrm{~m}^{2}$ odpowiednio o ok. $997 \mathrm{zl} / \mathrm{m}^{2}$ i ok. $255 \mathrm{zt} / \mathrm{m}^{2}$.

Natomiast przy przyjętym poziomie istotności $\alpha=0,05$ nie ma podstaw do odrzucenia $\mathrm{H}_{0}$ o braku istotnego wpływu bliskości lokalizacji mieszkania (BUS do200) od przystanku autobusowego.

\subsection{Alternatywna postać modelu}

W niniejszym badaniu do analizy przyjęto liniową postać modelu. Jednak w większości badań empirycznych modele hedonistyczne cen są modelami log-liniowymi, w których logarytm ceny objaśniany jest za pomocą liniowej funkcji ilościowych oraz jakościowych zmiennych objaśniających. Choć weryfikacja modelu liniowego (nr 1) wskazuje, że model ten spełnia założenia KMNK i dobrze dopasowuje się do danych, na potrzeby tego badania dodatkowo oszacowano również model log-liniowy o następującej postaci:

$\ln C E N A \_T R A N S=\beta_{0}+\sum_{k=1}^{K} \beta_{k i} X_{k i}+\varepsilon_{i}$

W modelu uwzględniono zmienne objaśniane, które okazały się mieć istotny wpływ dla liniowej postaci (model nr 2). Wyniki oszacowania modelu log-liniowego przedstawiono w tabeli 5.

W porównaniu do modelu $2 \mathrm{w}$ modelu log-liniowym (nr 3) poprawie uległ empiryczny poziom istotności parametrów zarówno dla kluczowej zmiennej METRO, jak i zmiennej BUS_do200. W przypadku zmiennej METRO, odrzucając $\mathrm{H}_{0}$ o braku wpływu na cenę mieszkania, pomylimy się ok. 1/100. Podobnie jak w przypadku modelu 2. Należy zatem przyjąć, że zmienna METRO istotnie wpływa na cenę. Oszacowany wpływ można zinterpretować

Tabela 5. Wyniki estymacji KMNK dla modelu log-liniowego (model $\mathrm{nr}$ 3)

\begin{tabular}{|c|c|c|c|c|c|}
\hline Zmienna & Współczynnik ${ }^{4}$ & Błąd stand. & t-Studenta & wartość p & \\
\hline METRO & $-2,3530 \mathrm{E}-5$ & $<0,0001$ & $-2,6358$ & 0,0095 & $* * *$ \\
\hline WLASN & 0,1121 & 0,0187 & 5,9959 & $<0,0001$ & $* * *$ \\
\hline BUS_do200 & 0,0409 & 0,0205 & 1,9900 & 0,0489 & $* *$ \\
\hline PU_do45 & 0,1266 & 0,0276 & 4,5887 & $<0,0001$ & *** \\
\hline PU_od45do60 & 0,0369 & 0,0146 & 2,5229 & 0,0129 & $* *$ \\
\hline Const & 8,8615 & 0,0240 & 368,9875 & $<0,0001$ & $* * *$ \\
\hline $\mathrm{N}$ & \multicolumn{5}{|c|}{126} \\
\hline $\mathrm{R}^{2}$ & \multicolumn{5}{|c|}{0,4304} \\
\hline Skoryg. $\mathrm{R}^{2}$ & \multicolumn{5}{|c|}{0,4066} \\
\hline
\end{tabular}

Uwagi: Zmienna zależna (Y): ln_CENA_TRANS; *, **, *** oznaczają poziom istotności odpowiednio: 0,$1 ; 0,05$ i 0,01 . 
następująco: wraz ze wzrostem odległości mieszkania od stacji metra o $1 \mathrm{~km}$ cena nieruchomości spada (ceteris paribus) o ok. 2,35\%.

W przypadku pozostałych zmiennych modelu należy przyjąć, że ich oszacowania są statystycznie istotnie różne od zera. W szczególności oszacowania wskazują, że: - własność (WLASN) w stosunku do prawa użytkowania wieczystego wpływa pozytywnie na cenę (ceteris paribus) o ok. $11,2 \%$;

- powierzchnia użytkowa mieszkania do $45 \mathrm{~m}^{2}$ wpływa pozytywnie na cenę w stosunku do mieszkań powyżej $60 \mathrm{~m}^{2}$ (ceteris paribus) o ok. $12,7 \%$;

- powierzchnia użytkowa mieszkania od 45 do $60 \mathrm{~m}^{2}$ wplywa pozytywnie na cene w stosunku do mieszkań powyżej $60 \mathrm{~m}^{2}$ (ceteris paribus) o ok. 3,7\%;

- odległość mieszkania od przystanku autobusowego nie większa niż $200 \mathrm{~m}$ w stosunku do mieszkań oddalonych o ponad $200 \mathrm{~m}$, wpływa pozytywnie na cenę (ceteris paribus) o ok. $4,1 \%$.

\section{Podsumowanie i wnioski}

Wyniki przeprowadzonego badania empirycznego potwierdziły hipotezę badawczą mówiącą, że lokalizacja stacji metra istotnie wpływa na kształtowanie się ceny pobliskich nieruchomości. Wykorzystując HMC oparty na równaniu regresji wielorakiej, wykazano, że wraz ze wzrostem odległości nieruchomości od najbliższej stacji metra o $1 \mathrm{~km}$, cena lokalu mieszkalnego spada o ok. $172 \mathrm{zl} / \mathrm{m}^{2}$ (model nr 2 liniowy) / 2,35\% (model nr 3 log-liniowy). Pomimo pożądanych własności modelu nr 2 (spełnienie założeń o normalności i homoskedastyczności składnika losowego, brak problemu współliniowości), zasadne wydaje się przyjęcie modelu w postaci log-liniowej (nr 3). Podyktowane jest to przede wszystkim lepsza możliwością interpretacyjną, wyższym poziomem dopasowania modelu oraz wyższymi poziomami istotności parametrów otrzymanych dla tego modelu.

Wyniki niniejszego badania pozwalają wypełnić lukę w krajowej literaturze w zakresie analizy wpływu dostępności metra na cenę nieruchomości. Po pierwsze, w odróżnieniu od istniejacych analiz, w badaniu wykorzystano ceny transakcyjne lokali mieszkalnych, zamiast cen ofertowych. Ponadto, do pomiaru odległości wykorzystano moduł GPS, dzięki czemu uwzględniono faktyczny dystans dzielący badane obiekty (w tym przeszkody na odcinku łączącym oba punkty). Przeprowadzona analiza opiera się na analizie rynku lokalnego, na który może wpłynąć efekt oddziaływania metra, nie włączając do analizy dzielnic, przez które nie przebiega linia metra. Co więcej, w modelu uwzględniono inne środki publicznego transportu zbiorowego (autobusy). W rezultacie oszacowana zależność pomiędzy lokalizacją stacji metra a ceną nieruchomości, uwzględnia to, czy w okolicy nieruchomości jest dostępna komunikacja autobusowa, która również może znacząco wpływać na cenę. Oszacowany model wykazał, że wpływ lokalizacji metra na ceny nieruchomości jest zdecydowanie niższy niż wykazywany dotychczas w krajowej literaturze lub w opracowaniach firm consultingowych (15-20\%), które nie biorą pod uwagę powyższych ograniczeń.

$\mathrm{Z}$ uwagi na ograniczoną liczbę obserwacji zasadne jest przeprowadzenie kolejnych badań z uwzględnieniem pozostałych dzielnic i rynku wtórnego. Niemniej ważne wydaje się również dalsze badanie wpływu lokalizacji komunikacji miejskiej, w tym przystanków autobusowych, na cenę nieruchomości, który w niniejszym badaniu okazał się stosunkowo wysoki.

\section{Przypisy}

1 Poza Bazyl (2009), której wyniki analizy zostaną przedstawione w późniejszej cześci artykułu.

2 Wykorzystano moduł pieszy GPS dostępny na stronie https://www.google.pl/maps. Do pomiaru odległości nieruchomości od Centrum Warszawy wykorzystano modul samochodowy GPS dostępny również na stronie https://www.google. $\mathrm{pl} / \mathrm{maps}$.

3 Dokładny wpływ zmiennej objaśniającej dany jest przez wartość liczby e podniesionej do potęgi równej wartości współczynnika, minus jeden $\left(e^{\beta}-1\right)$.

4 Zgodnie ze wzorem $e^{\beta}-1$ dokładny wpływ zmiennych objaśniających na cenę nieruchomości jest następujący:

\begin{tabular}{|l|c|c|c|}
\hline \multicolumn{1}{|c|}{ Zmienna } & $\begin{array}{c}\text { Współczynnik } \\
\boldsymbol{\beta}\end{array}$ & $\begin{array}{c}\text { Dokładny } \\
\text { wpływ } \\
\text { zmiennej }\end{array}$ & $\begin{array}{c}\text { Dokładna } \\
\text { zmiana } \\
\text { procentowa }\end{array}$ \\
\hline METRO & $-2,3530 \mathrm{E}-5$ & $-2,3530 \mathrm{E}-5$ & $-2,35 \%$ \\
\hline WLASN & 0,1121 & 0,1186 & $11,86 \%$ \\
\hline BUS_do200 & 0,0409 & 0,0417 & $4,17 \%$ \\
\hline PU_do45 & 0,1266 & 0,1350 & $13,50 \%$ \\
\hline PU_od45do60 & 0,0369 & 0,0376 & $3,76 \%$ \\
\hline
\end{tabular}




\section{Bibliografia}

Agostini, C.A. i Palmucci, G.A. (2008). The Anticipated Capitalisation Effect of a New Metro Line on Housing Prices. Fiscal Studies, 29(2), 233-256. http://doi.org/10.1111/j.1475-5890.2008.00074.x.

Bae, C.-H. C., Jun, M.-J. i Park, H. (2003). The impact of Seoul's subway Line 5 on residentia property values. Transport Policy, 10(2), 85-94 http://doi.org/10.1016/S0967-070X(02)00048-3.

Bazyl, M. (2009). Hedonic price model for Warsaw housing market, Working Papers, Department of Applied Econometrics, Warsaw School of Economics, 8, 1-16.

Bowes, D.R. i Ihlanfeldt, K.R. (2001). Identifying the Impacts of Rail Transit Stations on Residentia Property Values. Journal of Urban Economics, 50(1), 1-25, http:// dx.doi.org/10.1006/juec.2001.2214.

Damm, D., Lerman, S.R., Lerner-Lam, E. i Young, J. (1980). Response of Urban Real Estate Values in Anticipation of The Washington Metro. Jour nal of Transportation Economics and Policy, 14(3), 315-336.

Efthymiou, D. i Antoniou, C. (2013). How do transport infrastructure and policies affect house prices and rents? Evidence from Athens, Greece. Transportation Research Part A, 52, 1-22, http://doi. org/10.1016/j.tra.2013.04.002.

Gatzlaff, D.H. i Smith, M.T. (1993). The Impact of the Miami Metrorail on the Value of Residences Near Station Locations. Land Economics, 69(February), 54-66, http://dx.doi.org/10.2307/3146278.
Lin, J. i Hwang, C. (2004). Analysis of property prices before and after the opening of the Taipe subway system. The Annals of Regional Science, 38(4), 687-704, http:// dx.doi.org/10.1007/s00168003-0185-2.

Martínez, L. i Viegas, J. (2009). Effects of Transportation Accessibility on Residential Property Values: A Hedonic Price Model in the Lisbon Metropolitan Area. Transportation Research Record: Journal of the Transportation Research Board, 2115, 127-137, http://dx.doi.org/10.3141/2115-16

Rosen, S. (1974). Hedonic prices and implicit markets: product differentiation in pure competition. Journal of Political Economy, 82(1), 34-55, http:// dx.doi.org/10.1086/260169.

Sirmans, S., Macpherson, D. i Zietz, E. (2005). The composition of hedonic pricing models. Journal of Real Estate Literature, 13(1), 1-44.

Sun, W., Zheng, S. i Wang, R. (2015). The capitalization of subway access in home value: A repeatrentals model with supply constraints in Beijing. Transportation Research Part A: Policy and Practice, 80(October), 104-115, http:// dx.doi.org/10.1016/j. tra.2015.07.015.

Wooldridge J.M. (2003). Introductory econometrics: A modern approach. Mason, $\mathrm{OH}$ : Thomson/SouthWestern.

Zhang, X. i Jiang, Y. (2014). An empirical study of the impact of metro station proximity on property value in the case of Nanjing, China. Asian Development Policy Review, 2(4), 61-71. 